\title{
Access to virtual education in students of degree level in the State of San Luis Potosi
}

\section{Acceso a la educación virtual en alumnos de nivel licenciatura en el Estado de San Luis Potosí}

\author{
ALVARADO-SÁNCHEZ, Brenda†*, MORENO-DE-LEÓN, Romina Sinahí, MACÍAS-PÉREZ, José \\ Roberto and REYES-MUNGUÍA, Abigail
}

Universidad Autónoma de San Luis Potosí. Huasteca Zone Multidisciplinary Academic Unit. Romualdo Del Campo 501. Fracc. Rafael Curiel. Ciudad Valles, S.L.P. CP. 79060. Mexico.

ID $1^{\text {st }}$ Author: Brenda, Alvarado-Sánchez / ORC ID: 0000-0002-6077-2665, CVU CONACYT ID: 38716I

ID $1^{\text {st }}$ Co-author: Romina Sinahí, Moreno-De-León

ID $2^{\text {nd }}$ Co-author: José Roberto, Macías-Pérez / ORC ID: 0000-0001-7925-2494, CVU CONACYT ID: 17298

ID $3^{\text {rd }}$ Co-author: Abigail, Reyes-Munguía / ORC ID: 0000-0002-2151-7979, CVU CONACYT ID: 46743

DOI: $10.35429 /$ JCT.2020.12.4.12.16

Received: January 15, 2020; Accepted June 30, 2020

\begin{abstract}
The life changes associated with the health emergency caused by the SARS-CoV2 epidemic have tested the adaptation skills of the population, and the education sector has been no exception. This study aims to have an approach to the real panorama that the students of the Biochemistry Degree of the Faculty of Professional Studies of the Huasteca Zone of the Autonomous University of San Luis Potosi live with respect to the conditions that they have with the new form of learning. An electronic survey was used, solved by 232 students (76\%). Among the most important results, it was found that $85.7 \%$ of the students do not have an electronic device of exclusive use to carry out academic activities and that $10.8 \%$ do not have internet services at home, which can seriously affect their academic performance; situation that should be analyzed in due time.
\end{abstract}

New normality, Learning conditions, Digital gap

\begin{abstract}
Resumen
Los cambios de vida asociados a la emergencia sanitaria por la epidemia SARS-CoV2 han puesto a prueba las habilidades de adaptación de la población y, el sector educativo no ha sido la excepción. En este estudio se pretende tener un acercamiento al panorama real que viven los estudiantes de la Licenciatura en Bioquímica de la Facultad de Estudios Profesionales Zona Huasteca de la Universidad Autónoma de San Luis Potosí respecto a las condiciones que viven con la nueva forma de aprendizaje. Se utilizó una encuesta electrónica, resuelta por 232 alumnos (76\%). Dentro de los resultados más importantes, se encontró que un $85.7 \%$ de los alumnos no cuentan con un dispositivo electrónico de uso exclusivo para realizar actividades académicas y que un $10.8 \%$ no cuentan con servicios de internet en casa, lo que puede afectar gravemente su rendimiento académico; situación que deberá ser analizada en su momento.
\end{abstract}

Nueva normalidad, Condiciones de aprendizaje, Brecha digital

Citation: ALVARADO-SÁNCHEZ, Brenda, MORENO-DE-LEÓN, Romina Sinahí, MACÍAS-PÉREZ, José Roberto and REYES-MUNGUÍA, Abigail. Access to virtual education in students of degree level in the State of San Luis Potosi. Journal Computer Technology. 2020. 4-12:12-16.

\footnotetext{
* Correspondence to the author (Email: balvarado@uaslp.mx).

$\dagger$ Researcher contributing as first author.
} 


\section{Introduction}

For a long time, a large part of the education sector has incorporated technology as a work tool, however, this has been gradually but not mandatory. This resistance to change has arisen due to different circumstances, including myths about virtual and distance education, such as the belief that learning can only take place in the face-to-face mode, although there are also realities derived from the social context of the population in Mexico and from the natural history of education in our country. One of them is the access that students have to adequate technology that allows them to achieve learning through the use of digital media and, not only that they can access it, but also that they know its use and that the environment that surrounds them is favorable for its optimal use (CabralVargas, 2008).

The Faculty of Professional Studies of the Huasteca Zone of the UASLP is located in a region where at least two Nahuatl and Tenek ethnic groups converge, in addition to the mestizo population and a large part of the student body comes from medium and low economicsocial strata, it limits in a certain way their ability to access technological means that facilitate their learning in virtual mode. At the moment, it has been possible to demonstrate that socioeconomic conditions have an important influence on the educational performance of individuals, which impacts the development of the regions (Luna, et. Al, 2020) Which, in the current scenario Learning without a doubt has important repercussions, since the necessary tools for this involve the acquisition of various technological resources, as well as the proper handling of them, which entails training in their use, in some cases through payment systems.

At this time there is no diagnosis on the learning scenarios that are presented in the socalled new normal within the FEPZH, so it is essential to carry it out to identify those factors or deficiencies that can become areas of development opportunity and achieve the improvement of learning (Torres, 2020).
Therefore, the objectives of this study were to evaluate the digital services, electronic media and skills in ICT of the students of the Degree in Biochemistry of the FEPZH-UASLP, as well as to identify the academic needs presented by the student population.

\section{Methodology}

The disclosure of a link was requested to answer an electronic survey, the invitation was sent through the coordination of tutorials, with the application period from September 02 to 25. In the case of the Degree in Biochemistry, 232 students answered the survey out of a total of 302 students (76.8\%), one of the critical points of this is that we do not know if the students who did not answer the survey were because they did not have the means to access it since it was carried out in electronic format, however, depending on the current health emergency conditions, it was the most viable option to massively reach the population of students without putting their health at risk.

\section{Results}

Table 1 describes the general characteristics of the population studied and we can see that most of the participants are women and are concentrated in the fifth, first and ninth semester.

\begin{tabular}{|c|c|c|c|c|}
\hline \multicolumn{3}{|c|}{$\begin{array}{l}\text { No. of people who answered } \\
\text { the survey: }\end{array}$} & 232 & $100 \%$ \\
\hline \multicolumn{3}{|c|}{ No. of women: } & 165 & $67.2 \%$ \\
\hline \multicolumn{3}{|c|}{ No. of men: } & 76 & $32.7 \%$ \\
\hline \multicolumn{3}{|c|}{ Survey application period: } & $02 / 09 / 20$ & $25 / 09 / 20$ \\
\hline \multicolumn{3}{|c|}{ Age range: } & \multicolumn{2}{|c|}{17 to 23 years } \\
\hline \multicolumn{5}{|c|}{ No. of people per semester } \\
\hline First & Third & Fifth & Seventh & Nineth \\
\hline $\begin{array}{r}72 \\
(31.0 \%) \\
\end{array}$ & $\begin{array}{r}50 \\
(21.5 \%) \\
\end{array}$ & $\begin{array}{r}68 \\
(29.3 \%) \\
\end{array}$ & $\begin{array}{r}13 \\
(5.6 \%) \\
\end{array}$ & $\begin{array}{r}29 \\
(12.5 \%) \\
\end{array}$ \\
\hline
\end{tabular}

Table 1 Description of the population.

Regarding the academic situation of the students at the time of answering the survey, we can observe that the majority $(87.2 \%)$ of the population is regular student (data not shown). This information is relevant since at a given moment a follow-up can be done to determine how this value is modified or not after the August-December 2020 semester in which teaching will be practically in virtual mode. 

services

Access to electronic media and digital

Once the general characteristics of the population had been described, we proceeded to request information on the electronic media to which they have access and the digital services they have, for this, several questions were established that allow us to assess this aspect. When questioned about access to electronic devices for use in academic activities, it was found that $90.1 \%$ of students have at least one tool that allows them to carry out such work. However, $9.9 \%$ do not have an electronic device for exclusive use. With an answer to the previous question, it is understood that most of the students have at least one electronic device to carry out their academic activities, however, when asked how many people they should share them with, surprisingly $52.6 \%$ answered that they share the equipment with at least one person, reaching in some cases (10.3\%) to share it with more than 3 people (data not shown).

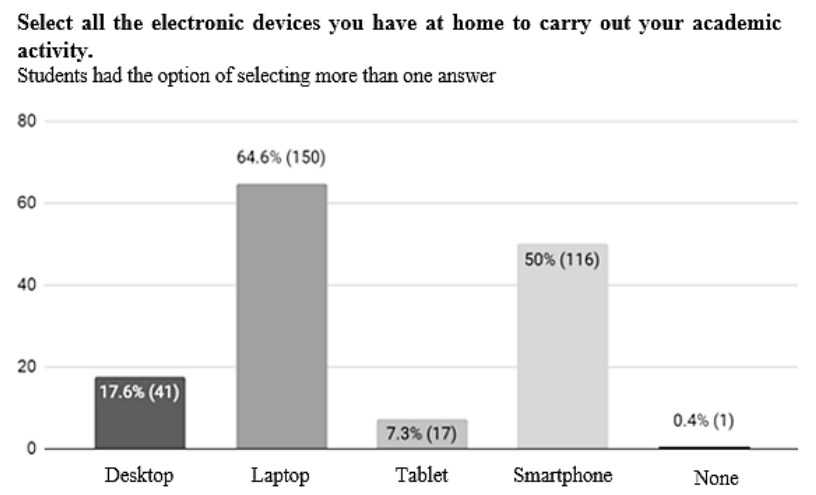

Graphic 1 Electronic devices available at home for students

In Graphic 1 we can see that $50 \%$ have at least a smartphone, however, only $64.4 \%$ have a laptop and $17.6 \%$ have a desktop computer.

Unlike similar surveys in other UASLP Faculties, the desktop computer is a device that is still used by a good part of the student population, it is probably related to the socioeconomic status in the region. Let us remember that generally a greater investment is required to acquire a laptop computer than a desktop one and that a large part of the student population at FEPZH is low-income.

Handling digital tools.
To have a good academic performance it is essential to have a good internet connection, so students were questioned about the type of service they currently have. To which $89.2 \%$ responded that they have a wireless connection, and a small part of the population of $2.5 \%$ does not have internet service at home or data plan.

That leaves $34.4 \%$ of the population that accesses academic content through a data plan, this is undoubtedly worth considering when selecting materials since they will undoubtedly consume a good part of their data plan and will have an impact on their economic and academic situation.

In addition to the situations already described, there are other conditions that affect access to learning materials; In this sense, $86.6 \%$ of the students reported having Wi-Fi connectivity problems, in addition to having problems with data connection (22.8\%), handling old or obsolete equipment (22.4\%), lack of skills in handling ICTs $(13.7 \%)$ and even power outages (36.2\%), see Graphic 2 .

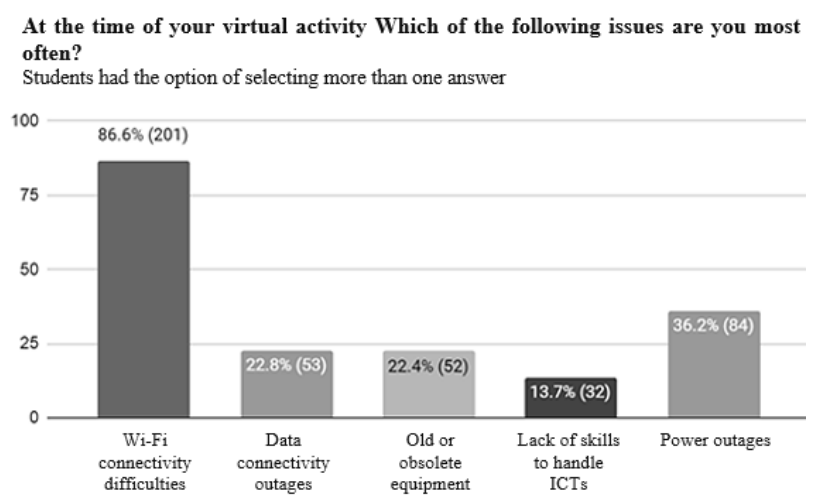

Graphic 2 Problems presented to access academic activities

The problem of internet connection is a generalized situation in the region due, among other things, to the geographical conditions that make it difficult for the signal to pass through, however, this situation has worsened due to the fact that a large number of families found themselves in need of hiring internet services in a hasty manner due to the health contingency, which has led to a saturation of services (MeraMosquera \& Mercado-Bautista, 2019). 
In addition to the problem with access to efficient Internet services, an important part of the students (33.8\%) is developing work activities, so this is another important factor when defining the learning activities to be developed since, in in some cases (73\%), working hours coincide totally or partially with school hours (data not shown). Although the majority of students who are working $(88.3 \%)$ are allowed access to their academic activities, the concentration and dedication they can give to these will not be the same as that of a student who is exclusively dedicated to studying (Suing, 2018).

\section{Ergonomics}

In the case of education, ergonomics has an impact on the academic performance of students. A simple example is the acquisition of furniture that allows you to sit comfortably for long periods of time, the installation of artificial light that facilitates reading and even the isolation of the area to reduce loud or annoying noises. Therefore, the real learning scenario of the students in which they are developing their academic activities was explored.

How would you rate your achievement in the immediately preceding semester?

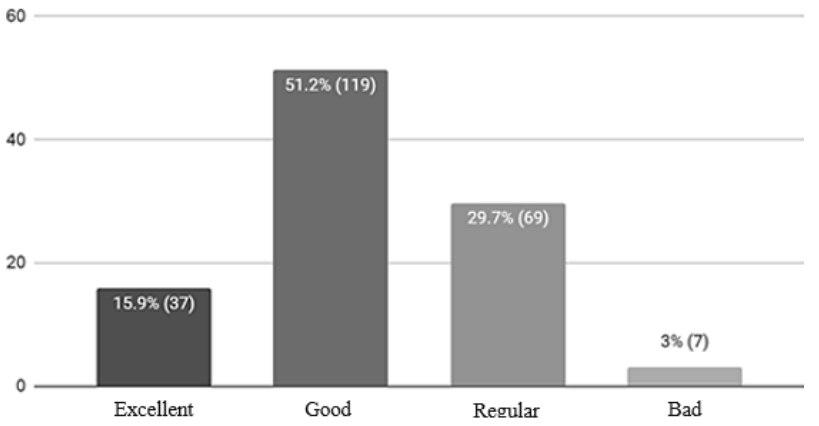

Graphic 3 Assessment of academic performance by students

It goes without saying that $54.5 \%$ of the students reported having distractors in their work areas (data not shown) and this coincides with the fact that it is approximately the same proportion of students who state that they use shared rooms to develop their school activities. Interestingly, $71.2 \%$ of the students declared that these distractors did not affect their academic performance (data not shown), a situation that can be evaluated when analyzing their academic condition at the end of this semester, as well as their perception of it; since, at this moment, only $3 \%$ of the population considers that their academic performance is bad (Graphic 3).
Academic needs.

One of the main objectives of this study was to explore the real conditions of access to learning for students of the Bachelor of Biochemistry, with the ultimate aim of influencing the teaching strategies used and therefore the academic performance of the students. Therefore, one of the questions they were asked was, How often do you require personalized or group advice from the teacher to understand a topic? To which only $32.3 \%$ answered that rarely and $0.4 \%$ never (Graphic 4 ).

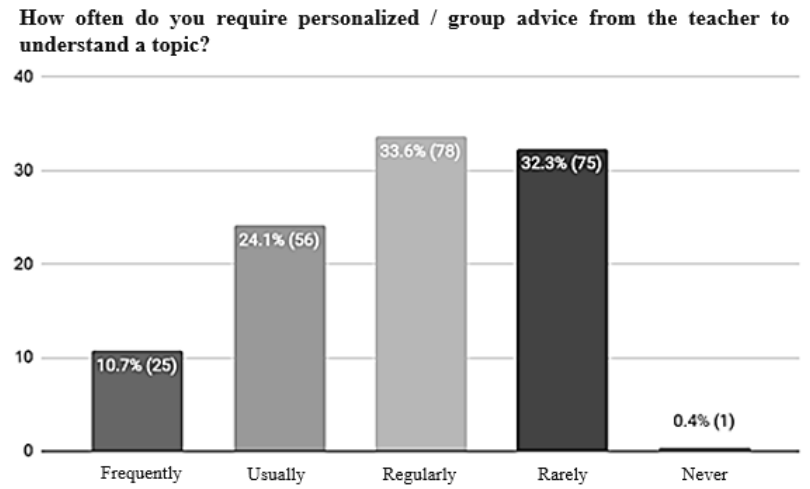

Graphic 4 Assessment requirements for learning

Given that the Biochemistry career has a significant proportion of practical subjects, students were questioned about the tools that allow them to better understand these types of topics, to which $78 \%$ stated that demonstrative practices are the ones that best allow them to understand topics, followed by tutorials $(67.6 \%)$ and simulators $(43.2 \%)$.

However, the skills of teachers in the generation, search and management of these types of tools are unknown. Regardless of this, it is obvious that the development of technological and innovation competences in teachers should be sought, since, although it is possible to restore normality in the educational environment, undoubtedly these types of tools are already part of the forms of learning of students (Bernate \& Guativa, 2020).

\section{Acknowledgments}

To the authorities of the Bachelor of Biochemistry, FEPZH-UASLP for their support in carrying out this research. 


\section{Conclusions}

It is necessary to design the teaching and / or learning activities taking into consideration that a portion of the study population does not have electronic devices for exclusive use and therefore their access to information will be limited to their availability. It is important to consider that only $89.2 \%$ of students have internet at home, so the rest will not be able to access digital services 24 hours a day, it is recommended to reduce the mandatory nature of synchronous sessions outside office hours. It is also important to take into consideration that a significant proportion of the students $(33.8 \%)$ are working, so the time they can dedicate to academic activities will be limited (data not shown). It is advisable to include videos, electronic presentations or readings in each topic or content to be reviewed, since these media are the ones that, from the student's perspective, provide the best results for student learning (data not shown). It is necessary to replicate the efforts to diagnose learning scenarios in the new normal, since as Yáñez et al. (2020) show, the forms of communication, as well as the technological tools available vary depending on the educational level that the students are studying, as well as the geographical region where they are. Undoubtedly, higher education is no exception, so educational institutions must carry out their own diagnoses to adapt the tools and train the teaching staff in their use.

\section{References}

Cabral-Vargas, B. (2008). Elementos necesarios para una modalidad de educación a distancia en bibliotecología. Investigación bibliotecológica, 22(46), 59-89.

Bernate, J. A., \& Guativa, J. A. V. (2020). Desafíos y tendencias del siglo XXI en la educación superior. Revista de ciencias sociales, 26(2), 141-154.

Lucio, P. B., Zimerman, A. A., \& Altamirano, C. A. L. (2020). Encuesta Nacional a Docentes ante el COVID-19. Retos para la educación a distancia. Revista Latinoamericana de Estudios Educativos, 50(ESPECIAL), 41-88.
Mera-Mosquera, A. R., \& Mercado-Bautista, J. D. (2019). Educación a distancia: Un reto para la educación superior en el siglo XXI. Dominio de las Ciencias, 5(1), 357-376.

Suing, D. J. N. (2018). La formación a distancia, una necesidad para la formación de los estudiantes. Polo del Conocimiento, 3(9), 287302.

Torres Martínez, L. L. A. (2020). Favorecer la expresión y apreciación artística en el preescolar. 